\title{
Valuing patents for accounting purposes
}

\author{
Serena Morricone
}

\section{Introduction}

Previous chapters have widely discussed why patent valuation is important. The growing value of patents is also associated with a relevant need for information for different corporate stakeholders. Since financial reporting represents the foremost channel of information between the firm and its stakeholders, the issue of accounting valuation of patents is far from being trivial.

The main objective of this chapter is to analyze accounting standards of different countries, such as the U.S. and Europe, and their implications for the accounting valuation of patents.

The chapter deals with two interrelated aspects. First, it presents the general problems of evaluating patents for accounting purposes, discussing the problems of recognition, measurement and disclosure. Second, it focuses on the main divergences in the accounting valuation of patents between European (International Financial Reporting Standards) and U.S. accounting standards (U.S. General Accepted Accounting Principles). This comparison between accounting valuation criteria is also compelling in the light of ongoing international harmonization of accounting standards. ${ }^{\mathrm{i}}$ In 2005 all European companies traded in stock markets have compulsory adopted the International Financial Reporting Standards (hereby IFRS). Recently, the U.S. SEC issued proposals that could allow U.S. companies to use IFRS for fiscal years ending on or after 15 December 2009 and could lead to mandatory transition to IFRS for domestic issuers starting for fiscal years ending on or after 15 December 2014. 
The chapter is organized as follows. The next section will deal with the general problems of evaluating patents for accounting purposes. Sections 3 and 4 will examine, respectively, initial recognition and measurement of patents highlighting the main divergences between U.S. GAAP and IFRS. Section 5 will analyze the measurement of patents after initial recognition. The last section will draw some conclusions from the evidence presented in the chapter.

\section{The general problems of evaluating patents for accounting purposes}

Accounting standard setters establish the accounting rules under which firms report financial results to external parties. Consequently, accounting standards aim to reduce processing costs for financial statement users by providing a commonly accepted language that managers can use to communicate with investors (Healy and Palepu, 2001).

However, in spite of the growing relevance of patents, accounting values do not thoroughly reveal the economic values created by patents. There are three main problems related to the accounting valuation of patents: initial recognition, measurement and disclosure.

The first one stems from the initial recognition that is the process of incorporating a patent in the balance sheet. It involves the accounting choice between capitalizing a patent in the balance sheet or expensing it in the income statement. Initial recognition criteria are different for purchased and internally generated patents. Thus, as discussed in the following sections, accounting standards generally allow capitalizing patents externally acquired, while those internally generated are mostly expensed. Even if from an economic perspective all patents could generate future benefits, however accounting standards requiring to expense those created internally are excluding a priori that they 
will generate future benefits. This asymmetric recognition substantially skews information provided by financial reports and significantly reduces the asset and equity values, above all for those small firms whose main assets are patents. This, in turn, might limit the comparability of the financial statements of companies that develop patents internally or buy them externally.

A second problem is related to the measurement of patents. Measurement refers to the process of determining the monetary value at which a patent is recognised in the balance sheet. This involves the selection of the particular basis of measurement that, in the case of patents, mostly coincides with the historical cost. The measurement of capitalized patents at historical cost provides backward-looking information. Thus, financial reports supply no indication of efficiency of use and future exploitation potential of patents. The measurement at fair value could provide forward-looking information on patents since fair value is the amount for which a patent could be exchanged between knowledgeable, willing parties in an arm's length transaction. However, the absence of public market prices of patents and the scarcity of comparable transactions make the evaluation of patents at fair value often unfeasible.

The third problem is related to the disclosure on patents and to the deficiencies in patent recognition and measurement. Actually, financial statements include notes and supplementary information that is relevant to the needs of users about patents capitalized in the balance sheet or expensed in the income statement. However, the disclosure of information on patents is particularly scarce and the details provided substantially rely on firm's willingness to disclose what is considered in most high-tech industries proprietary information. This created a high variation in the accuracy of information between and even within industries. In particular, for patents capitalized in the balance sheet, the notes to financial statement provide no indication of efficiency of 
use and future exploitation potential of patents and disclose little systematic information about the capacity of the company to generate future revenues from them. As well, for those patents to be expensed in the income statement accounting standards do not mandate the disclosure of supplemental information. The financial statement of Agilent Technologies provides an example of shortcoming in accounting disclosure (see Box 1).

\section{Box 1 - Agilent Technologies Inc.: Disclosure on IPRs capitalized.}

Agilent Technologies is one of the most innovative companies among US semiconductor industry holding a patents portfolio of more than 3200 U.S. patents. Despite Agilent Technologies "generate(s) patent and other intellectual property rights covering significant inventions and other innovations in order to create a competitive advantage" (Annual report, FY 2008: page 16), nevertheless, his notes to consolidated financial statements do not reveal qualitative useful information about patents capitalized.

\begin{tabular}{|c|c|c|c|c|c|c|}
\hline \multirow{2}{*}{ As of October 31, 2007 } & \multicolumn{6}{|c|}{ Other Intangible Assets } \\
\hline & \multicolumn{2}{|c|}{$\begin{array}{c}\text { Gross } \\
\text { Carrying } \\
\text { Amount }\end{array}$} & \multicolumn{2}{|c|}{$\begin{array}{l}\text { Accumulated } \\
\text { Amortization } \\
\text { (in millions) }\end{array}$} & \multicolumn{2}{|c|}{$\begin{array}{c}\text { Net Book } \\
\text { Value }\end{array}$} \\
\hline Purchased technology & $\$$ & 197 & $\$$ & 90 & $\$$ & 107 \\
\hline Trademark/Tradename & & 31 & & 1 & & 30 \\
\hline Customer relationships & & 67 & & 26 & & 41 \\
\hline Total & $\$$ & 295 & $\$$ & 117 & $\$$ & 178 \\
\hline As of October 31, 2008: & & & & & & \\
\hline Purchased technology & $\$$ & 281 & $\$$ & 124 & $\$$ & 157 \\
\hline Trademark/Tradename & & 32 & & 3 & & 29 \\
\hline Customer relationships & & 85 & & 43 & & 42 \\
\hline Total & $\$$ & 398 & $\$$ & 170 & $\$$ & 228 \\
\hline
\end{tabular}

We purchased $\$ 103$ million of other intangibles and recorded \$67 million of goodwill during 2008 relating to seven acquisitions and a purchase of the remaining unowned portion of a joint venture. Pro forma disclosures were not required for these acquisitions, as they were not material. Amortization of intangible assets was $\$ 53$ million in 2008 , $\$ 40$ million in 2007, and $\$ 24$ million in 2006. Future amortization expense related to existing purchased intangible assets is estimated to be \$47 million in 2009, \$43 million for 2010, \$39 million for 2011, \$31 million for 2012 , \$21 million for 2013, and $\$ 47$ million thereafter. On December 18, 2007, we completed the acquisition of Velocity11, a designer, manufacturer and marketer of robotic solutions. The aggregate purchase price was approximately $\$ 11$ million in cash used to purchase 100 percent of Velocityl1's outstanding common shares and vested common stock options that Velocity1 1 employees held on the closing date of the acquisition."

Although "purchased technology" represents more than $50 \%$ of total other intangible assets, the company does not disclose detailed information regarding its composition or how this asset could contribute to firm's competitive advantage. For those patents to be expensed in the 
income statement, Agilent Technologies describes the different research projects carried on and states "Due to the breadth of research and development projects across all of our businesses, there are a number of drivers of this expense" (Annual report, FY 2008: page 43). Nevertheless, the notes to consolidated financial statements instead of providing useful indication on what is financial magnitude of each research projects, describe only the overall amount of total expenditures.

Source: Agilent Technologies Inc., Annual report for the fiscal year ended October 31, 2008: page 89.

The three-abovementioned problems mostly stem from a mismatch between the economic attributes of patents and the accounting criteria set for their recognition in the balance sheet (Lev, 2001). Above all, the inherently high risk of patents negatively affects the firm's ability to estimate in a reliable way their future benefits. This in turns, often results into a full expensing of patents in the income statement.

\section{Recognition of patents}

The accounting valuation of patents is set by accounting standards related to intangible assets that are the International Accounting Standard No. 38 "Intangible Assets" (hereby IAS 38) for IFRS, and the FASB Concepts Statement No. 142 "Goodwill and Other Intangible Assets" (hereby FASB 142) for U.S. GAAP.

The initial recognition is the process of incorporating in the balance sheet a patent that satisfies certain criteria. As regards IFRS, in order to recognize patents as balance sheet assets, IAS 38 requires a company to demonstrate that:

1. the patent meets the definition of an intangible asset (existence of future economic benefits, control and identifiability);

2. it is probable that the expected future economic benefits that are attributable to the patent will flow to the entity; 
3. the cost of the patent can be measured reliably.

As regards the definition of intangible asset, IAS 38 prescribes that an intangible asset shall be recognized only when the three conditions are satisfied:

a) existence of future economic benefits,

b) control, and

c) identifiability.

The existence of future economic benefits is regarded as precondition to define an intangible assets. In particular the future economic benefits flowing from an intangible asset may include not only revenues from the sale of products or services, but also cost savings and other benefits resulting from the use of the asset (IAS 38, par. 17). For example, the use of a patent in a production process reduces future production costs rather than increase future revenues.

The control criterion refers to the company's ability to obtain future economic benefits and to restrict the access of others to those benefits (IAS 38, par. 13). The capacity of control the future economic benefits from an intangible asset generally arises from legal rights that are enforceable in a court of law. Therefore control criterion is always satisfied in case of patents.

The identifiability criterion requires that an intangible asset should be distinguished from goodwill. In particular, an asset meets the identifiability when:

- it is separable, that is capable of being separated or divided from the entity and sold, transferred, licensed, rented or exchanged, either individually or together with a related contract, asset or liability; or

- when it arises from contractual or other legal rights, regardless of whether those rights are transferable or separable from the entity or from other rights and obligations (IAS 38, par. 12). 
Besides the three-abovementioned conditions to define an intangible asset, IFRS specifies two criteria that qualify for recognition in the balance sheet. IAS 38 (par.21) clarifies that an intangible asset shall be recognised if, and only if, it is probable that the expected future economic benefits that are attributable to the asset will flow to the entity; and the cost of the asset can be measured reliably. As regards the concept of probability, it refers to the degree of uncertainty that the future economic benefits associated with the patent will flow to the company. The uncertainty that characterises the environment in which a company operates mostly affects the concept of probability. Consequently, the assessment of the degree of uncertainty of future economic benefits is made using reasonable and supportable assumptions that represent management's best estimate of the set of economic conditions that will exist over the useful life of the patent (IAS 38, par. 22).

The second criterion of reliable measurement requires that a patent possesses a cost or value that can be measured reliably. According to IASB Framework, information is reliable "when it is free from material errors and bias and can be depended upon by users to represent faithfully that which it either purports to represent or could reasonably be expected to represent" (IASB Framework, par. 31). When a patent meets the definition of intangible asset and the criteria of expected future economic benefits and reliable measurement are satisfied, the patent should be recognised in the balance sheet, otherwise it has to be expensed in the income statement.

As regards the U.S GAAP, accounting for patents is substantially similar to IFRS since, following the Norwalk agreement ${ }^{\mathrm{ii}}$, the U.S and European standard setters (respectively, FASB and IASB) pledged to make their financial reporting standards fully compatible. Consequently, differences between IFRS and U.S GAAP have been progressively reduced. iii $^{\text {in }}$ 
U.S GAAP definition of intangible assets and the related attributes that qualify an asset as intangible reflect the IASB definition. FASB Concepts Statement No. 6 "Elements of Financial Statements" and FASB Concepts Statement No. 142 "Goodwill and Other Intangible Assets" state that assets are probable future economic benefits obtained or controlled by a particular entity as a result of past transactions or events (FASB 6, par. 25) and intangible assets are assets that lack of physical substance (FASB No. 142, appendix F).

U.S GAAP definition includes the essential characteristics of an asset described by IFRS: it represents future economic benefits, it is a consequence of a past transaction or event and it is controlled by the company. FASB Concepts Statement No. 5 "Recognition and Measurement in Financial Statements of Business Enterprises" sets four criteria for recognition in the balance sheet. Consequently, in order to recognize a patent as an asset :iv

- it should meet the asset definition,

- it should have an attribute that is measurable with sufficient reliability,

- the information about it is capable of making a difference in users' decisions,

- the information is representationally faithful, verifiable, and neutral.

Recognition criteria are satisfied in the case of external acquisition of patent and of $R \& D$, whereas research and development costs and related internally generated patents do not meet the abovementioned criteria and are charged to expense as incurred.

In the case of business combination, patents always satisfy the condition for capitalization in the balance sheet. Actually, FASB Concepts Statement Business Combination" No. 141 (par. 3k) claims that an intangible assets could be capitalized apart from goodwill if: 
- it arises from contractual/legal rights or

- if it is separable, that is, it is capable of being separated or divided from the acquired entity and sold, transferred, licensed, rented, or exchanged.

In particular, Statement 141 specifies that intangible assets acquired in a business combination that do not meet certain criteria have to be included in the amount initially recognized as goodwill.

\begin{tabular}{|c|c|}
\hline $\begin{array}{l}\text { IFRS } \\
\text { - Patent meets the definition of an intangible } \\
\text { asset: } \\
\text { - existence of future economic benefits, } \\
\text { - control } \\
\text { - identifiability } \\
\text { - It is probable that the expected future } \\
\text { economic benefits that are attributable to } \\
\text { the patent will flow to the entity; } \\
\text { - The cost of the patent can be measured } \\
\text { reliably. }\end{array}$ & $\begin{array}{l}\text { U.S. GAAP } \\
\text { - Patent meets the definition of asset: } \\
\text { - existence of future economic benefits, } \\
\text { - consequence of a past transaction or event } \\
\text { - control by the company } \\
\text { - It has an attribute that is measurable with } \\
\text { sufficient reliability, } \\
\text { - The information about it is capable of making } \\
\text { a difference in user decisions, and } \\
\text { - The information is representationally faithful, } \\
\text { verifiable, and neutral }\end{array}$ \\
\hline
\end{tabular}

Table. 1 Recognition criteria for patents

\section{Initial measurement of patents}

Once recognition criteria are satisfied, accounting standards require determining the monetary amount at which the patent is to be recognised in the balance sheet. The initial measurement involves the selection of the basis of measurement, that differs between IFRS and U.S. GAAP and varies according to the different ways in which the asset arises.

As regards IFRS, IAS 38 distinguishes whether a patent:

- arises from an external acquisition or 
- it is internally developed.

In particular, in the case of external acquisition recognition criteria are always satisfied. Actually, the price paid to acquire the patent reflects both a signal about the probability that future economic benefits will flow to the company and, a reliable measure of the cost of the patent (IAS 38, par. 25-26). Conversely, in the case of internally generated patents, a company is less able to prove the existence of future economic benefits. Indeed, IAS 38 claims that it is particularly difficult to provide a reliable evaluation of the cost of an internally generated intangible because, in some cases, the cost cannot be distinguished from the cost of maintaining or enhancing the entity's internally generated goodwill or of running day-to-day operations (IAS 38, par. 51). Here we discuss how the initial measurement of patents changes between externally acquired and internally developed.

The external acquisition of patents involves either a separate acquisition or an acquisition in a business combination. In particular, the IFRS "Business Combination" No. 3 defines a business combination as a transaction or event in which an acquirer obtains control of one or more businesses. A business is defined as an integrated set of activities and assets that is capable of being conducted and managed for the purpose of providing a return directly to investors or other owners, members or participants.

In case of separate acquisition of the patent, the initial measurement is based on the purchase price, which could include import duties, non-refundable purchase taxes and any directly attributable cost (See Table 4).

When a patent is acquired in a business combination, the initial measurement is based on fair value, that is the amount for which a patent could be exchanged between knowledgeable, willing parties in an arm's length transaction (IAS 38, par.8). 
According to IAS 38, the acquiring company recognises separately from goodwill a patent of the acquiree if the asset's fair value can be measured reliably, irrespective of whether the patent had been recognised by the acquiree before the business combination (IAS 38, par. 34). Besides, if the patent of the acquiree is still under development, the acquiring company might recognize as an asset the in-process research and development project (IPR\&D) of the acquiree if the project meets the definition of an intangible asset (existence of future economic benefits, control and identifiability) and its fair value can be measured reliably. Although for tangible and financial assets the measurement of fair value could be normally obtained, the economic characteristics of intangible assets make particularly challenging the assessment of fair value with sufficient reliability. This measurement requires the availability of market prices in an active market or purchase prices of the most recent similar transactions. ${ }^{v}$ Nevertheless, as IAS 38 specifies, it is uncommon that for patents an active market with public prices exists. ${ }^{\mathrm{vi}}$ Moreover, as already discussed in Chapter 6, given the uniqueness of most patents and the scarce frequency of transactions, purchasing prices of similar patents may not provide sufficient evidence of the fair value. Consequently, in the absence of an active market and of exchange transactions for the same or similar patents, companies may use two main techniques for estimating fair values indirectly (IAS 38, par. 41). These valuation methods have been discussed in Chapter 6 and include the discounted cash flows method and the adoption of multiples reflecting current market transactions to indicators that drive the profitability of the patent (such as revenue, market shares and operating profit) or to the royalty stream that could be obtained from licensing the patent (as in the 'relief from royalty' approach). In particular, IAS 38 states that these valuation methods may be used for initial measurement in a business combination if their objective is to estimate fair value and if they reflect current transactions and 
practices in the industry (See Box 2 for an example).

\section{Box 2 - Estimation of fair value}

The 2008 annual report of Bayer (page 157) states that:

"the estimation of discounted cash flows from intangible assets is based on assumptions concerning:

- the outcomes of research and development activities regarding compound efficacy, results of clinical trials,

- the probability of obtaining regulatory approval in individual countries,

- long-term sales trends,

- possible selling price erosion due to generic competition in the market following patent expirations,

- the behavior of competitors (launch of competing products, marketing initiatives etc.)."

Source: Bayer 2008 Annual report: page 157.

As regards internally generated patents, IFRS admit their capitalization among development costs. Specifically, given the general difficulties in establishing whether an internally generated intangible asset meets the criteria for recognition, IFRS divides the generation process into a research phase and a development phase (See Table 2 for examples of research and development activities). ${ }^{\text {vii }}$ IAS 38 does not allow the capitalization of expenditures incurred during the research phase because a company cannot demonstrate that research activities will generate probable future economic benefits. Therefore, expenditures on research phase have to be reported in the income statement. The development phase is characterized by less uncertainty on future economic benefits and then the related expenditures could be capitalized in the balance sheet. However, if it is not possible to identify clearly when the development phase begins, the company has to treat the expenditure on the project as if it were incurred in the research phase only. 


\section{IFRS}

\section{Research activities:}

Activities aimed at obtaining new knowledge;

The search for, evaluation and final selection of, applications of research findings or other knowledge;

The search for alternatives for materials, devices, products, processes, systems or services;

The formulation, design, evaluation and final selection of possible alternatives for new or improved materials, devices, products, processes, systems or services;

Development activities:

Design, construction and testing of pre-production or pre-use prototypes and models; the design of tools, jigs, moulds and dies involving new technology;

Design, construction and operation of a pilot plant that is not of a scale economically feasible for commercial production;

Design, construction and testing of a chosen alternative for new or improved materials, devices, products, processes, systems or services.

\section{U.S. GAAP}

\section{Activities included in R\&D:}

Laboratory research aimed at discovery of new knowledge.

Searching for applications of new research findings or other knowledge.

Conceptual formulation and design of possible product or process alternatives.

Testing in search for or evaluation of product or process alternatives.

Modification of the formulation or design of a product or process.

Design, construction, and testing of preproduction prototypes and models.

Design of tools, jigs, molds, and dies involving new technology.

Design, construction, and operation of a pilot plant that is not of a scale economically feasible to the enterprise for commercial production.

Engineering activity required to advance the design of a product to the point that it meets specific functional and economic requirements and is ready for manufacture.

Activities excluded in $\mathbf{R} \& \mathbf{D}$ :

Engineering follow-through in an early phase of commercial production.

Quality control during commercial production including routine testing of products.

Trouble-shooting in connection with breakdowns during commercial production.

Routine, on-going efforts to refine, enrich, or otherwise improve upon the qualities of an existing product.

Adaptation of an existing capability to a particular requirement or customer's need as part of a continuing commercial activity.

Seasonal or other periodic design changes to existing products.

Routine design of tools, jigs, molds, and dies.

Activity, including design and construction engineering, related to the construction, relocation, rearrangement, or start-up of facilities or equipment other than (1) pilot plants and (2) facilities or equipment whose sole use is for a particular research and development project.

Legal work in connection with patent applications or litigation, and the sale or licensing of patents.

Source: FASB Statement No. 2, Accounting for Research and Development Costs, paragraphs 9-10; International Accounting Standards Board (IASB), IAS 38 Intangible assets, paragraphs 56,59.

Table. 2 Examples of research and development activities under IFRS 
In particular, an intangible asset arising from development phase shall be recognised if, and only if, a company can demonstrate all the following conditions (IAS 38, par. 57):

- the technical feasibility of completing the patent so that it will be available for use or sale.

- its intention to complete the patent and use or sell it.

- its ability to use or sell the patent.

- how the patent will generate probable future economic benefits. Among other things, the entity can demonstrate the existence of a market for the output of the patent or the patent itself or, if it is to be used internally, the usefulness of the patent.

- the availability of adequate technical, financial and other resources to complete the development and to use or sell the patent.

- its ability to measure reliably the expenditure attributable to the patent during its development.

Although IFRS allow capitalizing development costs, companies are seldom able to demonstrate that all the abovementioned conditions are satisfied. Actually, the management must use its judgment to evaluate whether technical and economic characteristics of each development project satisfy the accounting requirements. For example, the technical feasibility of completing a patent could be demonstrated in pharmaceutical and biotech industries by the regulatory approval of products. In particular, some companies consider as a strong indication that the above criteria are met and hence as starting point for the capitalisation of internal development costs when a filing for approval had been made in a major market and approval was considered highly probable (see Box 3 for an example). 


\section{Box 3- Capitalization of development costs}

In the 2008 annual report GlaxoSmithKline (page 108) states:

"Research and development expenditure is charged to the income statement in the period in which it is incurred. Development expenditure is capitalised when the criteria for recognising an asset are met, usually when a regulatory filing has been made in a major market and approval is considered highly probable."

In other cases, the regulatory approval might not provide a sufficient basis for capitalising the development costs as Merck KGaA 2008 annual report testifies (page 85):

"The costs of research and development are expensed in full in the period in which they are incurred. Development expenses in the Pharmaceuticals business sector cannot be capitalized since the high level of risk up to the time that pharmaceutical products are marketed means that the requirements of IAS 38 are not satisfied in full. Costs incurred after regulatory approval are insignificant. In the same way, the risks involved until products are marketed means that development expenses in the Chemicals business sector cannot be capitalized."

Source: GlaxoSmithKline 2008 Annual report: page 108; Merck KGaA 2008 Annual report: page 85.

In order to demonstrate the technical and commercial feasibility a company should constantly assess the potential market during the various stages of development and evaluate whether its competitors might have marketed similar products or technologies that consequently undermine the probability of economic benefits. Moreover, IAS 38 indicates that a business plan showing the technical, financial and other resources needed in the development project could provide evidence of the availability of resources to complete and use an intangible asset. As well, a lender's indication of its willingness to fund the plan could demonstrate the availability of external finance.

Once the criteria for capitalisation have been met, the cost of an internally generated patent comprises all directly attributable costs necessary to create, produce, and prepare the patent to be capable of operating in the manner intended by management. 


\section{Internally generated patents}

Initial measurement $\rightarrow$ Production cost

\section{Attributable costs:}

- Costs of materials and services used or consumed in generating the patent;

- Employee benefits for the personnel involved in the generation of the patent;

- Directly attributable costs of patent application: fees to register or transfer a legal right;

- Design, construction and testing of preproduction prototypes and models.

\section{Externally acquired patents}

Initial measurement $\rightarrow$ Separate Acquisition: Purchase price

$$
\rightarrow \text { Business Combination: Fair value }
$$

Attributable costs:

- Purchase price, including import duties and nonrefundable purchase taxes, after deducting trade discounts and rebates;

- Costs of employee benefits and professional fees.

\section{Not attributable costs:}

- Costs incurred in using or redeploying a patent;

- Initial operating losses, such as those incurred while demand for the patent's output builds up;

- Costs of introducing a new product or service (including costs of advertising and promotional activities);

- Administration and other general overhead costs.

Source: IAS 38 Intangible assets, paragraphs 27-29, 66-67.

\section{Table. 3 Initial measurements according to IFRS}

As regards the U.S GAAP, the initial measurement of patents is substantially similar to IFRS for what concerns external acquisitions of patents and R\&D acquired in a business combination. As discussed in the previous section, U.S GAAP exclude from recognition in the balance sheet expenditures in the development stage and related internally generated patents.

The initial measurement of patents and $R \& D$ acquired in a business combination is based on fair value, which is defined in paragraph 5 of FASB Statement "Fair Value 
Measurements" No. 157 as the price that would be received to sell an asset or paid to transfer a liability in an orderly transaction between market participants at the measurement date. FASB Concepts Statement No. 142 "Goodwill and Other Intangible Assets" specifies that the fair value of an intangible asset shall be determined based on the assumptions that market participants would use in pricing the asset. Besides, the cost of a group of assets acquired in a transaction other than a business combination is allocated to the individual assets acquired on the basis of the relative fair values and shall not give rise to goodwill.

The initial measurement at fair value under U.S. GAAP substantially reflects the indications of IFRS previously discussed. In particular, companies generally apply the discounted cash flows method in the measurement of fair value. Examples of initial measurement at fair value can be found in Box 4 .

\section{Box 4 - Initial measurement at fair value}

In the 2007 annual report of Merck Sharpe and Dhome, we find the following (page 10):

"The fair value of intangible assets, including acquired research, is based on significant judgments made by management, and accordingly, for significant items, the Company typically obtains assistance from third party valuation specialists. [...] For intangible assets, including acquired research, the Company typically uses the income approach, which estimates fair value based on each project's projected cash flows. Future cash flows are predominately based on a net income forecast of each project, consistent with historical pricing, margins and expense levels of similar products. Revenues are estimated based on relevant market size and growth factors, expected industry trends, individual project life cycles, and the life of each research project's underlying patent, if any. Expected revenues are then adjusted for the probability of technical and marketing success and the resulting cash flows are discounted at a risk-adjusted discount rate."

Similarly, Motorola states in 2007 annual report (page 126): 
"The value to in-process research and development was determined using expected future cash flows discounted at average risk adjusted rates reflecting both technological and market risk as well as the time value of money. Historical pricing, margins and expense levels, where applicable, were used in the valuation of the in-process products. The in-process research and development acquired will have no alternative future uses if the products are not feasible."

Source: Merck Sharpe and Dhome 2007 Annual report: page 10; Motorola 2007 Annual report: page 126.

\section{Measurement of patents after initial recognition: amortization and impairment test}

The measurement of patents after the initial recognition require firstly the definition of useful life of the patents. In particular, according to IAS 38 the useful life is:

a) the period over which an asset is expected to be available for use by an entity; or

b) the number of production or similar units expected to be obtained from the asset by an entity.

FASB Concepts Statement No. 142 "Goodwill and Other Intangible Assets" provides a similar definition claiming that useful life is the period over which the asset is expected to contribute directly or indirectly to the future cash flows of that entity.

In particular, both IFRS and U.S GAAP require defining whether the useful life of an intangible asset is finite or indefinite and, consequently, assessing the period over which the asset is expected to generate net cash inflows for the company. In the estimation of useful life, companies should consider several factors that entail economic, technological and legal characteristics of intangible assets (see Table 5). Based on an analysis of these relevant factors, an intangible asset is regarded as having an indefinite useful life when there is no foreseeable limit to the period over which the asset is expected to generate future economic benefits. However, in the case of patents, the 
future profitability is limited by legal terms that restrict the period over which the company controls the economic benefits. In particular, IAS 38 states the useful life shall not exceed the period of the contractual or other legal rights and may be shorter depending on the period over which the entity expects to use the asset. ${ }^{\text {viii }}$ Similarly, FASB Concepts Statement No. 142 claims that the useful life of the asset is considered to be indefinite if no legal, regulatory, contractual, competitive, economic, or other factors limit the useful life of an intangible asset to the reporting entity. Thus, patents are generally considered as having a finite useful life.

\section{IFRS:}

\section{Factors determining the useful life:}

- The expected usage of the asset by the entity and whether the asset could be managed efficiently by another management team;

- Typical product life cycles for the asset and public information on estimates of useful lives of similar assets that are used in a similar way;

- Technical, technological, commercial or other types of obsolescence;

- The stability of the industry in which the asset operates and changes in the market demand for the products or services output from the asset;

- Expected actions by competitors or potential competitors;

- The level of maintenance expenditure required to obtain the expected future economic benefits from the asset and the entity's ability and intention to reach such a level;

- The period of control over the asset and legal or similar limits on the use of the asset, such as the expiry dates of related leases; and

- Whether the useful life of the asset is dependent on the useful life of other assets of the entity.

\section{U.S. GAAP:}

- The expected use of the asset by the entity;

- The expected useful life of another asset or a group of assets to which the useful life of the intangible asset may relate;

- Any legal, regulatory, or contractual provisions that may limit the useful life;

- The entity's own historical experience in renewing or extending similar arrangements regardless of whether those arrangements have explicit renewal or extension provisions. In the absence of that experience, the entity shall consider the assumptions that market participants would use about renewal or extension (consistent with the highest and best use of the asset by market participants), adjusted for entity-specific factors.

- The effects of obsolescence, demand, competition, and other economic factors (such as the stability of the industry, known technological advances, legislative action that results in an uncertain or changing regulatory environment, and expected changes in distribution channels).

- The level of maintenance expenditures required to obtain the expected future cash flows from the asset (for example, a material level of required maintenance in relation to the carrying amount of the asset may suggest a very limited useful life)

Source: FASB Statement No. 142 (par. 11) and IAS 38 (par. 90). 


\section{Table. 5 Factors determining the useful life of intangible assets}

Other than goodwill whose useful life is always indefinite, the identification of intangible asset other than patents with an indefinite useful life strictly depends upon company's judgment of asset profitability.

\section{Box 5 - Example of assets with indefinite useful life}

For example, in the pharmaceutical industry, most of companies evaluate trademarks as assets having indefinite useful life regardless of their legal lives. For instance, GlaxoSmithKline states in the (2008 financial report page 130):

"Indefinite life brands comprise a portfolio of Consumer Healthcare products acquired with the acquisitions of Sterling Winthrop, Inc. in 1994, Block Drug Company, Inc. in 2001 and CNS, Inc. in 2006. [...] Each of these brands is considered to have an indefinite life, given the strength and durability of the brand and the level of marketing support. The brands are in relatively similar stable and profitable market sectors, with similar risk profiles, and their size, diversification and market shares mean that the risk of market-related factors causing a reduction in the lives of the brands is considered to be relatively low. The Group is not aware of any material legal, regulatory, contractual, competitive, economic or other factor which could limit their useful lives. Accordingly, they are not amortised."

In contrast, Novartis operates in the same industry of GlaxoSmithKline and evaluates acquired in-process research and development project as having indefinite useful life (2008 financial report page 183):

"The useful lives assigned to acquired intangible assets are based on the period over which they are expected to generate economic benefits, commencing in the year in which they first generate sales or are used in development. Acquired intangible assets are amortized on a straight-line basis over the following periods:

- Trademarks: over their estimated economic or legal life with a maximum of 20 years;

- Product and marketing rights: 5 to 20 years;

- Core development technologies: over their estimated useful life, typically 15 to 30 years;

- Software: 3 years;

- Others: 3 to 5 years. 
In-Process Research \& Development (IPR\&D) is the only class of separately identified intangible assets that is not amortized, but IPR\&D is tested for impairment on an annual basis or when facts and circumstances warrant an impairment test."

Source: GlaxoSmithKlin 2008 Annual report: page 130; Novartis 2008 Annual report: page 183.

Following the definition of a finite or indefinite useful life, IFRS and U.S GAAP require that an intangible asset with a finite useful life be amortized, whereas an intangible asset with an indefinite useful life is not amortized but tested for impairment loss. Given that patents are generally considered as having a finite useful life, they will be systematically amortized over their useful lives.

The amortisation process requires the systematic allocation of the depreciable amount of a patent over its useful life. Thus, amortisation requires the definition of:

- the depreciable amount of the patent, and

- the residual value.

In particular, the depreciable amount represents the initial cost of patent less its residual value that is the estimated amount that an entity would currently obtain from disposal of the asset. However, both IFRS and US GAAP suggest to set the residual value to zero unless there is a commitment by a third party to purchase the patent at the end of its useful life; or residual value can be determined by reference to an active market for the asset and it is probable that such a market will exist at the end of the asset's useful life (FASB 142, par. 13: IAS 38 par. 100). An example of patent amortization is presented in Box 5.

\section{BOX 6 - Example of patent amortization}

A patented technology is expected to be a source of net cash inflows for at most 20 years. The 
carrying amount of the patent, that is the amount at which the patent is recognised in the balance sheet, is $\$ 100.000$.

The company has a commitment from a third party to purchase that patent in five years for 60 per cent of the value of the patent at the date it was acquired, and the entity intends to sell the patent in five years.

Depreciable amount $=$ carrying amount - residual value $=100.000-60.000=40.000$

Patent useful life $=5$ years

Yearly amortization rate $=40.000 / 5=8.000$

Amortisation begins when the patent is available for use and the amortisation method used should reflect the pattern in which the patent's future economic benefits are expected to be consumed by the company. If that pattern cannot be determined reliably, the straight-line method (constant depreciation) shall be used.

IFRS and U.S GAAP require that a company review at least at each financial year-end the amortisation period and the amortisation method in order to estimate whether the expected useful life of the patent is different from previous estimates or there has been a change in the expected pattern of consumption of the patent's future economic benefits. Moreover, IFRS and U.S GAAP also recommend testing patents for impairment whenever there is an indication that the asset may be impaired.

As regards intangible asset with an indefinite useful life, IFRS and U.S GAAP require that they will not be amortised but only tested for impairment loss. It should be noted that rarely a patent is judged to have an indefinite useful life, therefore the adoption of the impairment test to measure patent value after initial recognition is quite rare.

While the accounting requirements for amortization are consistent between IFRS and U.S GAAP, slight differences exist in definition of impairment test between the two accounting standards. 
Under U.S. GAAP the impairment test consists of a comparison of the carrying amount of an intangible asset with its fair value measured as undiscounted cash flows. Thus, the impairment test consists of a comparison of the fair value of an intangible asset with its carrying amount that is the amount at which an asset is recognised in the balance sheet. If the carrying amount of an intangible asset exceeds its fair value, an impairment loss shall be recognized in an amount equal to that excess. Subsequent reversal of a previously recognized impairment loss is prohibited.

According to IFRS, impairment test is performed comparing the carrying amount of an asset with the recoverable amount, which is the is the higher between the asset's fair value less costs to sell and the asset's value in use. In particular, value in use represents the future cash flows discounted to present value by using a pretax, market-determined rate that reflects the current assessment of the time value of money and the risks specific to the asset for which the cash flow estimates have not been adjusted. Thus, only if the carrying amount of the asset exceeds the recoverable amount, an impairment loss for the difference is recognized.

\section{Conclusions}

This chapter has examined the issue of accounting valuation of patents highlighting the main similarities and differences between IFRS and U.S. GAAP.

Whereas previous chapters have focused on the economic valuation of patents, this chapter has firstly identified the general problems of evaluating patents for accounting purposes. In particular, it has discussed the shortcomings stemming from the measurement of patents both at historical cost and at fair value. The measurement of capitalized patents at historical cost provides backward-looking information. Thus, 
financial reports supply no indication of efficiency of use and future exploitation potential of patents. The measurement at fair value could provide forward-looking information on patents since fair value is the amount for which a patent could be exchanged between knowledgeable, willing parties in an arm's length transaction. However, the absence of public market prices of patents and the scarcity of comparable transaction make difficult the evaluation of patents at fair value.

Moreover, the chapter has discussed how a company should recognize and measure patents highlighting the main differences between IFRS and U.S. GAAP. Although IFRS, differently from U.S. GAAP, could permit the capitalization among development costs of patents internally generated, however companies are seldom able to demonstrate that conditions for capitalization are satisfied.

\footnotetext{
${ }^{\mathrm{i}}$ In order to achieve a higher comparability of financial statements and consequently a broader integration of capital markets across countries, the international harmonization of accounting standards has been undertaken since 2002. In particular, accounting harmonization aims at making financial reporting consistent around the world through two-pronged approaches: the adoption of one single set of accounting standards and, at the same time, the progressive convergence between accounting standards. Regarding the adoption, at the present time, more than one hundred countries permit or require some or all firms to replacing national GAAPs with International Financial Reporting Standards (IFRS). Regarding convergence between accounting standards, some countries such as U.S., Japan, and China prefer to converge their standards with IFRS, so that eventually the two sets of standards will be the same.

ii The Norwalk agreement is a memorandum of understanding issued in 2002 in which the FASB and the IASB formalised their commitment to the convergence of US GAAP and IFRS.

iii For example, the SEC removed the reconciliation requirement for non-U.S. companies that are registered in the United States and use IFRS. Recently, SEC issued a preliminary plan that could allow some of the largest public companies in the United States to use IFRSs for fiscal years ending on or after 15 December 2009 and could lead to mandatory transition to IFRSs for domestic issuers starting for fiscal years ending on or after 15 December 2014.

${ }^{\text {iv }}$ FASB Concepts Statement No. 5 specifies also that recognition criteria are subject to a pervasive cost-benefit constraint: the expected benefits from recognizing a particular
} 
item should justify perceived costs of providing and using the information. Recognition is also subject to a materiality threshold: an item and information about it need not be recognized in a set of financial statements if the item is not large enough to be material and the aggregate of individually immaterial items is not large enough to be material to those financial statements.

v IAS 38 defines active market as a market in which all the following conditions exist:

(a) the items traded in the market are homogeneous;

(b) willing buyers and sellers can normally be found at any time; and

(c) prices are available to the public.

${ }^{\mathrm{vi}}$ For example, in some jurisdictions, an active market may exist for freely transferable taxi licences, fishing licences or production quotas. However, an active market cannot exist for brands, newspaper mastheads, music and film publishing rights, patents or trademarks, because each such asset is unique. (IAS 38 Intangible assets, paragraph 78). vii Specifically, research is conceived as an original and planned investigation undertaken with the prospect of gaining new scientific or technical knowledge and understanding. Conversely, the development phase is the application of research findings to a plan or design for the production of new or substantially improved materials, devices, products, processes, systems or services before the start of commercial production or use.

viii Besides, IAS 38 states that If the contractual or other legal rights are conveyed for a limited term that can be renewed, the useful life of the intangible asset shall include the renewal period(s) only if there is evidence to support renewal by the entity without significant cost. (IAS 38 Intangible assets, paragraph 94) 